\title{
THE JUDICIAL USE OF INTERNATIONAL HUMAN RIGHTS LAW IN NEW ZEALAND
}

\author{
Andrew S Butler* \\ Petra Butler ${ }^{* *}$
}

In this essay we briefly examine the judicial use of international human rights law in New Zealand. In particular, we identify the relevant sources of international human rights law for New Zealand and the possible methods of application of international human rights law in New Zealand's domestic judicial system, we assess the actual significance accorded to international human rights law, and attempt to account for the marked increase in use of international human rights law by New Zealand judges.

This essay concentrates on judicial use of international human rights law. It should however be noted that the use of such law in New Zealand is not confined to the judicial arena. As Paul Hunt and Margaret Bedggood have illustrated, ${ }^{1}$ there has been substantial use of international human rights law in other fora such as parliamentary select committees, and in Human Rights Commission reports. In addition, all proposals to Cabinet for new legislation must certify compliance with relevant international obligations (including human rights norms) or else contain an explanation as to why the legislation should proceed

* Senior Lecturer, Faculty of Law, Victoria University of Wellington, Barrister of the High Court of New Zealand, Bell Gully Buddle Weir Research Fellow (Wellington).

** First and Second State Examination in Law, Lower Saxony, Germany, LLM (VUW), Doctor of Laws (Göttingen).

1 P Hunt \& M Bedggood, "The International Law Dimension of Human Rights in New Zealand" in G Huscroft \& P Rishworth (eds) Rights and Freedoms (Brooker's, Wellington, 1995) ch 2 at 58-62. 
notwithstanding inconsistency with those obligations. ${ }^{2}$ Moreover, international complaint mechanisms have been used by New Zealanders who claim an interference with rights guaranteed by certain international human rights treaties. ${ }^{3}$

\section{RELEVANT SOURCES OF INTERNATIONAL HUMAN RIGHTS LAW IN NEW ZEALAND}

The generally accepted sources of international law are

- custom

- $\quad$ general principles

- treaties

Of these sources of law, the most relevant for international human rights purposes is treaty law. Customary international law has yet to develop an extensive settled jurisprudence of human rights obligations - the universalisation of international human rights standards through the adherence of many states to the various human rights treaties does however open up possibilities in this area and there has been much debate ${ }^{4}$ as to whether the Universal Declaration of Human Rights represents customary international law in the human rights field. Nor has the concept of "general principles of international law" made great strides in expanding the reach of international human rights law absent a treaty. However, once a state is subject to a treaty-based human rights obligation, international treaty monitoring bodies have been quite creative in the evolution and application of "general principles of international law" specially tailored to human rights norms. ${ }^{5}$

2 See Cabinet Office, Department of the Prime Minister and Cabinet, Cabinet Office Manual (1996) paras 5.26 and App 6 at 122 and 124 .

3 See the discussion of the New Zealand Council of Trade Unions complaint to the International Labour Organisation (ILO) alleging violations of Conventions 87 and 98 in Hunt \& Bedggood above $n 1$ at 61 . As at the date of writing some 8 communications have been made to the Human Rights Committee under the (first) Optional Protocol to the International Covenant on Civil and Political Rights.

4 See eg I Brownlie, Principles of Public International Law (4th ed Oxford, Clarendon Press, 1990) 570.

5 See generally J G Merrills, The Development of International Law by the European Court of Human Rights (Manchester University Press, 1988). 
Relevant human rights treaties for New Zealand include: 6

- $\quad$ the International Covenant on Civil and Political Rights ("the ICCPR") (1966)

- the International Covenant on Economic, Social and Cultural Rights ("ICESCR") $(1966)^{8}$

- the International Convention on the Elimination of All Forms of Racial Discrimination ("Race Convention") (1965) ${ }^{9}$

- the International Convention on the Elimination of All Forms of Discrimination against Women ("Women's Convention") (1979) ${ }^{10}$

- the United Nations Convention on the Rights of the Child ("Child Convention") $(1989)^{11}$

- $\quad$ various International Labour Organisation ("ILO") Conventions. ${ }^{12}$

At the same time there are in the international human rights arena other statements, declarations, opinions of experts, etc, which carry great weight and which are often looked to

6 A broader view of what is embraced by the notion of human rights treaties is evident in K Keith, "The Application of International Human Rights Law in New Zealand" (1997) 32 Texas ILJ 401, 403-404. Sir Kenneth would include conventions in relation to kidnapping, genocide, slavery, hostages, obscene publications and so on as human rights instruments. Without disagreeing with that view, but in light of space contraints, we propose to focus on a more limited range of international treaties.

$7 \quad R v$ Goodwin (No 2) [1990-92] 3 NZBORR 314, 321 (CA) (art 9(1)); Simpson v Attorney-General [Baigent's case] (1994) 1 HRNZ 42 (CA) (art 2(3)); and Tavita v Minister of Immigration (1993) 1 HRNZ 30, 35-6 (CA) (arts 23(1), 24(1) and 24(3)).

8 Lawson v Housing New Zealand (1996) 3 HRNZ 285, passim (HC) and Auckland Provincial District Local Authorities' Officers IOUW below n 12 (art 10(2)).

9 Re "Exposing the AIDS Scandal" (1993) 1 HRNZ 170, 179 (IPT) (art 4) and Wheen v Real Estate Agents Licensing Board (1997) 4 HRNZ 15, 28 (HC).

10 NRHA v Human Rights Commission (1997) 4 HRNZ 37 (HC) and Auckland Provincial District Local Authorities' Officers IOUW below n 12 (art 11(2(b)).

11 Tavita above $\mathrm{n}$ (CA) (arts 9(1) and 9(4)) and Puli'uvea v Removal Review Authority (1996) 2 HRNZ 510, 516-517 (CA) (arts 3(1), 8, 9 and 16).

12 Tranz Rail Ltd (t/a Interisland Line) v New Zealand Seafarers' Union [1996] 1 ERNZ 216 (EC) (Convention 68) and Auckland Provincial District Local Authorities' Officers IOUWv Onehunga Borough Council (1989) 2 NZELC 96, 956 (LC) (Conventions 3, 103 and 156). 
in determining the appropriate international human rights standard in a given situation. In particular, the following documents, though not treaties, have been referred to by New Zealand courts:

- $\quad$ the Universal Declaration of Human Rights ("UDHR") (1948) $)^{13}$

- the Siracusa Principles on the Limitation and Derogation Provisions in the International Covenant on Civil and Political Rights $(1984)^{14}$

- $\quad$ the United Nations Declaration against Religious Intolerance $(1981)^{15}$

- the Declaration on Elimination of Discrimination against Women (1967). ${ }^{16}$

Finally, frequent reference has been made to provisions of, and jurisprudence under, regional human rights treaties to which New Zealand is not and will not be a party. In particular, the courts have made extensive use of European Convention jurisprudence. ${ }^{17}$ This jurisprudence has been used both to explore the meaning of similarly worded or closely related articles of the ICCPR, ${ }^{18}$ and, in a more general way, to establish relevant international standards by reference to which the New Zealand Bill of Rights Act 1990, the Human Rights Act 1993, the Immigration Act 1987, and so on should be interpreted. ${ }^{19}$

\section{HOW INTERNATIONAL HUMAN RIGHTS LAW MAY BE USED IN NEW ZEALAND}

There are a number of ways in which international human rights law may be employed before New Zealand courts.

13 Van Gorkom v Attorney-General [1977] 1 NZLR 535, 542 (SC); Baigent's case above $\mathrm{n} 7$ at 82 (art 8); Lawson above n 8 passim (art 25(1)); Quilter v Attorney-General (1996) 3 HRNZ 1, 22 (HC) ("Quilter (HC)"); NRHA v Human Rights Commission above n 10; and $R v$ Gardiner (1997) 4 HRNZ 7, 10 (CA) (art 12).

14 Quilterv Attorney-General (1997) 4 HRNZ 170, 192 (CA, per Thomas J dissenting in part) ("Quilter (CA)").

15 Re J [an infant]; DGSWv B (1995) 2 HRNZ 99 (HC).

16 Van Gorkom above $\mathrm{n} 13$ at $542(\operatorname{art} 10(1))$.

17 References have also been made to Inter-American Convention decisions. See eg Baigent's case above $\mathrm{n}$ 7 at 83 (per Hardie Boys J) where the Velásquez Rodríguez case is referred to.

18 Tavita above $\mathrm{n} 7$ at 36-39; $R v$ L (1993) 1 HRNZ 310, 320-321 (CA).

$19 R v B(1994) 1$ HRNZ 1, 11-13 (HC); Police $v$ Kohler (1993) 1 HRNZ 303 (CA); Tavita above n 7 at $40 ; R v$ Coghill (1995) 2 HRNZ 125, 139-140 (CA). 
The fundamental proposition of which sight must not be lost is that as a matter of New Zealand law, Parliament may exercise its sovereignty in a manner inimical to New Zealand's international obligations (including human rights obligations) by enacting legislation which is inconsistent with those obligations. Should Parliament choose to do so, it is the duty of the courts to give effect to that decision. ${ }^{20}$

For many years it was thought that international law in general had little impact on domestic law unless it had been incorporated into New Zealand law by statute. ${ }^{21}$ To hold otherwise, it was believed, would permit the executive to make law without reference to Parliament by the expedient of entering into international treaties (treaty-making being an exclusive function of the Crown). That said, the courts were prepared to accommodate international law within the domestic sphere in some situations. Thus, customary international law had domestic effect as part of the common law without the need for legislative action. ${ }^{22}$ (This of course only to the extent that the rule of customary international law was not inconsistent with a statute.) Furthermore, on occasion, the courts would attempt to construe a statute in a manner consistent with international obligations, though there was no obligation to do so. ${ }^{23}$

20 See eg Richardson J in Ashby $v$ Minister of Immigration [1981] 1 NZLR 222, 229 (CA): "if the terms of domestic legislation are clear and unambiguous they must be given effect in our Courts whether or not they carry out New Zealand's international obligations." See also Re Bennett (1993) 2 HRNZ 358, 361 (HC); Bailey v Whangarei District Court (1995) 2 HRNZ 275, 287 (HC); and Mangawaro Enterprises Ltd v Attorney-General [1994] 2 NZLR 451, 457-458 (HC) (though note comment below). A rider should be added that on a number of occasions Lord Cooke of Thorndon stated that some rights were so fundamental that not even Parliament could deprive persons of those rights. These comments have yet to be given effect to, and many commentators doubt whether the judges could lawfully act upon these sentiments. See also Mangawaro Enterprises at 458 where Gallen J suggested in obiter that in an extreme case international instruments might be used by the courts to impugn domestic law.

21 In Ashby above n 20 at 224 Cooke J said: "It is elementary that international treaty obligations are not binding in domestic law until they have become incorporated [by an Act of Parliament]."

22 See eg Marine Steel Ltd $v$ Government of the Marshall Islands [1981] 2 NZLR 1 (HC) and Governor of Pitcairn $v$ Sutton [1995] 1 NZLR 426 (CA).

23 See eg Van Gorkom above n 13, where Cooke J referred to international human rights documents in the course of determining that certain regulations had been made ultra vires. 
However, the notion that international law requires specific parliamentary activity to have domestic effect no longer holds sway, particularly in the field of human rights. ${ }^{24}$ Thus, the courts have accepted that it is appropriate to use international treaty law, and jurisprudence thereunder, to interpret domestic law in a number of ways.

First, the Court of Appeal has accepted the general proposition that, "the Court should strive to interpret legislation consistently with the treaty obligations of New Zealand."25 This should occur, "whether or not the legislation was enacted with the purpose of implementing the relevant text." 26 The result is that interpretation by reference to treaty law is no longer optional, but required, unless the domestic statute is unambiguously incompatible with the treaty obligation.

Second, international human rights provisions and jurisprudence are used to interpret specific provisions of New Zealand human rights statutes. This flows naturally from the general proposition stated above. But it is particularly apposite in the human rights field because many New Zealand human rights statutes make explicit reference to the international antecedents which have prompted their enactment and which inspired their wording. ${ }^{27}$ These references have been taken by the courts to represent implicit permission, and in some

24 For a useful article on the extent to which parliamentary activity ought to be required before international obligations can have domestic effect, see J B Elkind \& A Shaw, "The Municipal Enforcement of the Prohibition against Racial Discrimination: A Case Study on New Zealand and the 1981 Springbok Tour" (1988) 55 BYIL 189.

25 Puli'uvea above $\mathrm{n} 11$ at 516-517

26 New Zealand Airline Pilots Association Inc v Attorney-General [1997] 3 NZLR 269, 289 (CA). With respect to the Employment Contracts Act 1991, see eg New Zealand Seafarers' Union above $n 12$ (reference to ILO Convention 68 as regards provision of food and water at no charge to employees); the Maternity Leave and Employment Protection Act 1980, see eg Auckland Provincial District Local Authorities' Officers IOUW above n 12 (concepts of "key position" and "reasonably practicable" in MELP Act determined with extensive reference to relevant ILO conventions, and recommendations, ICESCR and the Women's Convention); the Guardianship Act 1968, see B v M [1997] 3 NZLR 202 (HC) (meaning of s 17 "affected" determined by reference to art 23 of the ICCPR).

27 In addition to Recital (b) of the Bill of Rights discussed below, see also the Long Titles to the Race Relations Act 1971, the Human Rights Commission Act 1977, the Human Rights Act 1993 (which replaces the 1971 and 1977 Acts), and the Privacy Act 1993. See also s 4(1) of the Human Rights Act which lists as one of the functions of the Human Rights Commission the ability to report to the Prime Minister on action needed to ensure "better compliance with standards laid down in international instruments on human rights" and on the "desirability of New Zealand becoming bound by any [international] instrument." 
cases implicit command, to consider relevant international treaties and jurisprudence in interpreting domestic law. Indeed, while many provisions of domestic human rights statutes differ in their wording from their international antecedents, specific references to those antecedents has been regarded as legitimating judicial reliance on international jurisprudence.

A good example is Recital (b) of the Long Title to the New Zealand Bill of Rights Act 1990 ("the Bill of Rights") which records that the 1990 statute is designed, "To affirm New Zealand's commitment to the International Covenant on Civil and Political Rights". As Cartwright J observed in Bailey $v$ Whangarei District Court, ${ }^{28}$ the effect of this recital is that, "The New Zealand Bill of Rights Act transparently acknowledges its genesis in the ICCPR and sets out to encapsulate the principles contained in the Covenant." Recital (b) and its statement of purpose have been frequently referred to in order to justify interpretations of the New Zealand Bill of Rights Act which are consistent with the ICCPR and with the jurisprudence of the Human Rights Committee under the ICCPR and other relevant international jurisprudence. For example, in NRHA v Human Rights Commission, Cartwright J referred to Recital (b) as "acknowledg[ing] the international framework from which its [ie the Bill of Rights'] principles derive" and then referred to international jurisprudence to assist her in determining the meaning of "discrimination" in section 19(1) of the Bill of Rights. ${ }^{29}$

There are limits to the use of international materials in interpreting domestic human rights statutes. In particular, if Parliament has deliberately chosen to under-incorporate an international obligation, it will be difficult to convince the courts to remedy the deficiency. Thus, in $R v$ Barlow, ${ }^{30}$ Richardson J noted that while the ICCPR contains a general affirmation of the right to liberty and security of the person (article 9(1)) the New Zealand Bill of Rights Act does not. His honour regarded this departure from the wording of the ICCPR as "a deliberate decision on the part of the Legislature." Hence it was not possible to introduce the wider ICCPR guarantee as an aspect of the rights protected by the Bill of Rights. ${ }^{31}$ Similarly, in BHP NZ Steel Ltd $v O^{\prime} \mathrm{Dea}^{32}$ the High Court was invited to hold that opinions expressed by a trade unionist in relation to employment matters were covered by the notion of "political

28 Bailey above $\mathrm{n} 20$ at $287(\mathrm{HC})$.

29 Above n 10 at 55.

30 (1995) 2 HRNZ 635 (CA). See also Quilter (CA) above n 14 at 217 (per Keith J).

31 Ibid at 655.

32 (1997) 4 HRNZ 456 (HC). 
opinion" in section 21 of the Human Rights Act 1993. Reliance was placed on the ICCPR which protects persons from discrimination based on, inter alia, "political or other opinion". The High Court declined to extend the political opinion discrimination ground to trade union activities. Having referred to the parliamentary history of the provision and its predecessors, the court stated: ${ }^{33}$

In our view the Court cannot ignore the fact that the New Zealand parliament in the Human Rights Act has chosen to incorporate into domestic law only some of the rights recognised in various international covenants and conventions. In those circumstances the Court cannot use the generality of provisions in the international instruments to increase the scope of what our sovereign Parliament has decided should apply domestically. Further, although in a sensitive and important area such as this words should not be read down, where Parliament has deliberately provided protection for some rights which enjoy international recognition, but not others, it would be wrong for a Court to stretch or manipulate the clear words of a statute so as to provide protection in a greater or different area than Parliament has determined should apply.

That said, where ICCPR provisions have not been incorporated into New Zealand's human rights legislation, a legislative prohibition against reliance upon the ICCPR provisions will not necessarily be implied. Thus, in $B v M, 34$ the High Court used article 23 of the ICCPR which concerns family rights to assist in the interpretation of the Bill of Rights and hence give a particular interpretation to the word "affected" found in section 17 of the Guardianship Act 1968. This, even though there is no provision in the Bill of Rights which directly corresponds to article 23. Similarly, in Baigent's case $e^{35}$-discussed in more detail below - the Court of Appeal by a majority rejected the Crown's submission that it was inappropriate to award monetary compensation for breach of the Bill of Rights in the absence of a remedies provision in the Bill of Rights. In so doing, the majority judges placed particular reliance on the existence of a remedies clause in the ICCPR.

As even this brief examination of the case law indicates few criteria have emerged on the issue of under-incorporation. Ultimately much discretion is left in the hands of individual judges to determine the significance to be attached to differences in language between the

33 Ibid at $470-471$

34 Above $\mathrm{n} 26$.

35 Above $n 7$. 
international instruments and domestic law. From a practitioner's point of view this is unsatisfactory.

Third, international human rights norms may well be considered by the courts as a mandatory relevant consideration to which administrators and Ministers must have regard when exercising statutory (and other) discretions. This use of international human rights law has proven to be controversial.

In the 1981 decision of Ashby $v$ Minister of Immigration, it had been held by the Court of Appeal that it was only when a statute, "expressly or by implication identifies a consideration as one to which regard must be had that the Courts can interfere for failure to take it into account." 36 Coupled with the traditional "elementary" proposition that "international treaty obligations are not binding in domestic law until they have become incorporated" in a statute, it was clear that judicial review of administrative decisions made without reference to international obligations would be difficult to successfully pursue. Some members of the Ashby court did leave open the possibility that certain international obligations "might be of such overwhelming or manifest importance that the Courts might hold that Parliament could not possibly have meant to allow [them] to be ignored."37 But clearly, the manner of expression indicated a high threshold to be met.

However, in Tavita $v$ Minister of Immigration, ${ }^{38}$ the Court of Appeal signalled a bolder approach. In the course of argument in that case, counsel for the Crown had submitted that in determining whether to remove Mr Tavita from New Zealand the Minister of Immigration was "entitled to ignore the [relevant] international instruments". While not having to make a final determination on this submission, the Court labelled it "an unattractive argument". ${ }^{39}$ Moreover, the Court observed that: ${ }^{40}$

Legitimate criticism could extend to the New Zealand Courts if they were to accept the argument that, because a domestic statute giving discretionary powers in general terms does not mention international human rights, norms, or obligations, the Executive is necessarily free to ignore them.

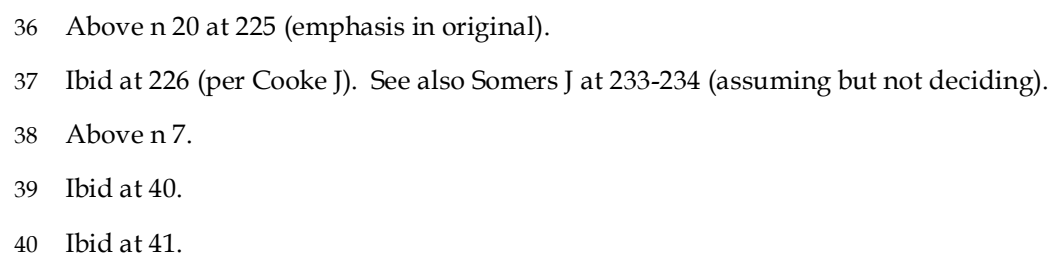


Interestingly, Tavita prompted an overhaul of the Immigration Service's guidelines. ${ }^{41}$ These now contain an explicit acknowledgement of New Zealand's international obligations under the ICCPR and the Child Convention and require officials to take into account and give substantial weight to particularised considerations which flow from these obligations in determining whether to seek removal of overstaying family members from New Zealand. ${ }^{42}$

Accepting that relevant international human rights obligations are matters to which regard must be had in the exercise of statutory (or other) discretions, the much harder issue is the weight which such obligations ought to be accorded in assessing the impugned decision. This issue has yet to receive full attention in New Zealand. ${ }^{43}$ Most probably the proper weight to be given international obligations will depend on a number of factors such as (a) the nature of the obligation; (b) how directly relevant or on point the international provision is; (c) the type of discretion involved; (d) the subject-matter of the legislation; and so on. At the same time, however, it must be recalled that generally speaking New Zealand courts are reticent to overturn an administrative decision on the ground that insufficient weight was attached to a relevant consideration. Such an exercise could be seen as entering into the

41 See the useful discussion in M Poole, "The Use and Abuse of International Instruments" in New Zealand Law Society Public Law Intensive (Wellington: New Zealand Law Society, 1998) 13 at 19-20. See also Elika $v$ Minister of Immigration [1996] 1 NZLR 741 (HC)

42 In later cases, the Court of Appeal has emphasised that Tavita requires consideration of international human rights obligations in substance rather than in form. Thus, where immigration officials had actually had regard to the sorts of considerations which the ICCPR and the Child Convention required, the Court of Appeal held that a decision to make a removal order was validly made, notwithstanding that the actual texts of the international instruments had not been specifically referred to. See eg Puli'uvea above $\mathrm{n} 11$ at 514. See in a different context Lawson above $\mathrm{n} 8$ at 335 .

43 In Ashby, the question was whether the Minister of Immigration had unlawfully exercised his discretion to grant visas to the visiting South African international rugby team. It had been argued for the applicants that (a) New Zealand's international human rights obligations were a relevant consideration to which the Minister was bound to have regard, and (b) further that those obligations so clearly opposed apartheid South Africa and were of "such dominating importance" as to "require the Minister to refuse visas." The court refused to accept this argument, Cooke J emphasising the sensitive nature of immigration law and the general latitude given by the statute, Richardson J regarding the issue as nonjusticiable and Somers J believing that whatever was required to be considered by the Minister had in fact been considered. 
merits of the decision actually made, something which the judges are generally reluctant to do. ${ }^{4}$

Lawson $v$ Housing New Zealand indicates that consideration of international obligations along with an attempt to weigh them in a balancing exercise may well suffice to discharge the Tavita requirements. In Lawson, a challenge was made to Housing New Zealand's move to market rentals for state housing tenants. It was submitted, inter alia, that such a move was inconsistent with rights declared in the ICCPR, the ICESCR and the UDHR. In rejecting this submission, Williams J referred to relevant New Zealand case law and observed that, "the authorities demonstrate it is not for this Court to judge whether the Government of New Zealand has fully complied with those obligations. It is sufficient for this Court to reach the view that the Government has plainly made efforts to balance the competing factors." 45 The evidence established to His Honour's satisfaction that this balancing exercise had been undertaken. He concluded that, "Whether New Zealand has fulfilled its international obligations is a matter on which it may be judged in international forums but not in this Court." 46

On this approach predominant weight need not be assigned to international human rights norms. ${ }^{47}$ This would be in line with English authority. In $R v$ Secretary of State for the Home Department, ex $p$ Brind, ${ }^{48}$ the House of Lords held that an open-ended ministerial discretion could not be read down by reference to standards set out in the unincorporated European Convention on Human Rights. Said Lord Bridge of Harwich: ${ }^{49}$

44 See eg $R v$ Home Secretary, ex $p$ Brind [1991] 1 AC 696, 762-763 (HL, per Lord Ackner). See also Lord Roskill at 750 and Lord Lowry at 766-767.

45 Above $\mathrm{n} 8$ at 334.

46 Ibid.

47 However, weight must be given to them. Thus, in Mohamed $v$ Minister of Immigration, HC Wellington 11 November 1996 AP 262/95, Chisholm J held that the Deportation Review Tribunal's decision not to overturn the deportation of the Mohameds was flawed because no meaningful consideration had been given to the situation of the Mohameds' children if deportation were to proceed, with far too much attention being paid to the deceptive way in which the Mohameds had applied for refugee status in New Zealand.

48 Above $\mathrm{n} 44$

49 Ibid at 748 (Lord Roskill concurring). See also Lord Ackner at 761-762. 
[W] here Parliament has conferred on the executive an administrative discretion without indicating the precise limits within which it must be exercised, to presume that it must be exercised within Convention limits would be to go far beyond the resolution of an ambiguity.

That said, the status of Brind in New Zealand is uncertain. In Tavita, the Court of Appeal did not consider it relevant to the issues before it but nonetheless referred to it as "in some respects a controversial decision". ${ }^{50}$

Again it will be seen that the application of international human rights norms to administrative discretions is itself a highly discretionary exercise. No criteria have emerged to assist practitioners or judges in determining the extent to which the international dimension is to be regarded as a mandatory relevant consideration.

\section{THE SIGNIFICANCE ACCORDED INTERNATIONAL HUMAN RIGHTS LAW IN NEW ZEALAND}

In light of the possible applications of international human rights norms in New Zealand outlined above, what actual significance has been accorded to them in the case law? This question can be answered by reference both to frequency of reference and to meaningfulness of consideration and prominence of the international human rights dimension in reaching a decision. What follows is not a scientific evaluation but rather one which reflects our impression of a substantial increase in the awareness of, and willingness to apply, international human rights standards.

\section{A Frequency of reference}

A check of the index to the specialist law report series, The Human Rights Reports of New Zealand (HRNZ) (and its predecessor The New Zealand Bill of Rights Reports (NZBORR)), indicates reasonably frequent reference to international human rights provisions and jurisprudence. Of the more than 200 cases reported, some 35 contain references to the ICCPR, 21 to the European Convention, 7 to the UDHR, 4 to the ICESCR, 4 to the Race Convention and 1 to the Women's Convention. As regards international jurisprudence, it would have to be admitted that reference to Human Rights Committee jurisprudence and its General Comments has been low. References to Committee views have occurred on at least 5 occasions, ${ }^{51}$ while General Comments have been referred to in perhaps 2 cases. ${ }^{52}$ This

50 Above $\mathrm{n} 7$ at 40

51 Goodwin (No 2) above $\mathrm{n} 7$ at 321; Baigent's case above n 7 passim; Martin $v$ District Court at Tauranga (1994) 1 HRNZ 186, 199 (HC); $R v$ B above $n 19$ at 12 (HC); Quilter (CA) above $n 14$ passim. 
doubtless reflects problems of access to, and unfamiliarity with, the Committee's documentation and work. Frequency of reference to European Convention jurisprudence is significantly higher with some 20 references. This is perhaps not surprising in light of easier access $^{53}$ to the European Human Rights Reports which are held at many law libraries in New Zealand.

\section{B Meaningfulness of Discussion and Prominence of International Human Rights Law}

In a number of cases, international human rights law receives passing attention: discussion of international human rights is confined to acknowledgement or reproduction of relevant provisions and little else. However, in many others there is a substantial amount of space devoted to consideration of international human rights law.

In Tavita, some 4 pages of the report are devoted to citation from, and a discussion of, two "distinctly relevant"54 judgments of the European Court of Human Rights as well as relevant provisions of the ICCPR and the Child Convention in determining whether the Minister of Immigration's decision to decline an appeal against Mr Tavita's removal from New Zealand was lawful. Ultimately, the court adjourned the proceedings so that the Minister could reconsider his decision in light of the relevant international human rights norms. Indeed, as noted earlier the effect of Tavita was a redrafting of the Guidelines for officials with an explicit direction to consider international human rights obligations in immigration decisionmaking. ${ }^{55}$

International human rights norms featured prominently in Quilter $v$ Attorney-General, 56 though the exact scope of these norms was sharply contested. That case considered two issues: (a) was it discriminatory on grounds of sex or sexual orientation to exclude same sex couples from marriage contrary to section 19 of the Bill of Rights; (b) if yes, could the Marriage Act 1955 be read in a manner consistent with the right to be free from

52 Martin (HC) above $\mathrm{n} 51$ and Quilter (CA) above $\mathrm{n} 14$.

53 Problems of access to international human rights jurisprudence has been judicially noted. In Tavita above $\mathrm{n} 7$ at 36 Cooke $\mathrm{P}$ discussed two "distinctly relevant" European Court of Human Rights judgments which had not been cited in argument, emphasising that there was "no criticism" of counsel who had little time to prepare and "such decisions are not always easy to locate."

54 Above $\mathrm{n} 7$ at 36

55 See above text at $\mathrm{n} 41$.

56 Quilter (CA) above $\mathrm{n} 14$ 
discrimination on those grounds. For the plaintiffs it was submitted that article 26 of the ICCPR was relevant to the issue, especially since the Human Rights Committee had indicated in its views in Toonen $v$ Australia that sexual orientation was a prohibited ground of discrimination under that provision. ${ }^{57}$

In holding that there was no discrimination within the meaning of section 19, Keith J devoted some two-and-a-half pages of the report to a discussion of article 26 and General Comment 18 on non-discrimination, as well as to article 23 of the ICCPR on family life. Similarly, in reaching the opposite conclusion, Thomas J devoted almost 4 pages to a discussion of articles 26 and 23, with extended references to Human Rights Committee jurisprudence, to the Committee's General Comment and to the Women's Convention.

But undoubtedly Baigent's case represents the most significant use of international human rights norms to date by a New Zealand court. In that case, the plaintiffs had allegedly been subjected to an unreasonable search and seizure by the police contrary to section 21 of the Bill of Rights. They sought monetary compensation for breach of that right. For the Crown it was submitted that since the Bill of Rights contains no clause explicitly permitting the courts to grant remedies in the case of violation, it was not possible to award monetary compensation for breach of section 21. On the other hand, counsel for the plaintiffs submitted that, notwithstanding the absence of a remedies provision, regard had to be had to article 2(3) of the ICCPR. That provision reads:

Each State Party to the present Covenant undertakes:

(a) To ensure that any person whose rights or freedoms as herein recognized are violated shall have an effective remedy, notwithstanding that the violation has been committed by persons acting in an official capacity;

(b) To ensure that any person claiming such a remedy shall have his right thereto determined by competent judicial, administrative or legislative authorities, or by any other competent authority provided for by the legal system of the State, and to develop the possibilities of judicial remedy;

(c) To ensure that the competent authorities shall enforce such remedies when granted

In light of this provision, it was argued, New Zealand courts were obliged to develop remedies appropriate to vindicate the plaintiffs' rights including monetary compensation.

57 (1995) 69 ALJ 602 (HRC). 
The Court of Appeal agreed with the plaintiffs' submission. On this basis, and with reference to other reasons, the court declared that monetary compensation was a remedy available under the Bill of Rights.

Greatest weight was attached to the ICCPR in the judgment of Casey J. In contrast to the other judgments, the ICCPR was the principal plank of his Honour's analysis. Recalling interpretative principles relevant to the Bill of Rights which had been established in earlier cases, Casey J stated that article 2(3) of the ICCPR was "[o]f particular relevance" in the instant case. ${ }^{58}$ He quoted article 2(3) in full, noted the purpose expressed in Recital (b) of the Bill of Rights, and continued: ${ }^{59}$

I do not regard the absence of a remedies provision in the Act as an impediment to the Court's ability to "develop the possibilities of judicial remedy" as envisaged by art 2(3)(b). The rights and freedoms affirmed are fundamental in a civilised society and justify a liberal purposive interpretation of the Act .... Its purpose being the affirmation of New Zealand's commitment to the Covenant (including art 2(3)(b)), it would be wrong to conclude that Parliament did not intend there to be any remedy for those whose rights have been infringed. ...

By its accession to the First Optional Protocol to the Covenant on 26 August 1989, New Zealand accepted individual access by its citizens to the United Nations Human Rights Committee for violations of rights under the Covenant, where they have been unable to obtain a domestic remedy. The Act reflects Covenant rights, and it would be a strange thing if Parliament, which passed it one year later, must be taken as contemplating that New Zealand citizens could go to the United Nations Committee in New York for appropriate redress, but could not obtain it from our own Courts.

It will be seen that these passages from Casey J's judgment proceed on a number of interrelated points of great significance to our discussion.

First, there is his Honour's determination to make New Zealand law accord with a relevant ICCPR provision. Second, there is invocation of the Long Title to legitimate reference to and reliance upon relevant ICCPR provisions in order to introduce a remedial jurisdiction which is not explicitly bestowed upon the courts by the Bill of Rights. Third, there is an acceptance of the futility of resistance to the application of the ICCPR in New

58 Above $\mathrm{n} 7$ at 73 .

59 Ibid at 73-74. 
Zealand, in light of the availability of international complaint mechanisms. Indeed, Cooke P for the Court of Appeal a few months earlier in Tavita had stated that in determining the impact which ICCPR obligations were to have on statutory discretions in future cases, ${ }^{60}$

an aspect to be borne in mind may be one urged by counsel for the appellant: that since New Zealand's accession to the Optional Protocol the United Nations Human Rights Committee is in a sense part of this country's judicial structure, in that individuals subject to New Zealand jurisdiction have direct rights of recourse to it.

All of these points demonstrate that international human rights obligations have moved centre-stage and that they are to be taken seriously.

In his judgment, Hardie Boys J also placed great emphasis on the international law dimension. His Honour referred to article 2(3) of the Covenant and to article 8 of the UDHR. The latter declares:

Everyone has the right to an effective remedy by the competent national authorities for acts violating the fundamental rights granted him by the constitution or by law.

He too referred to the Long Title of the Bill of Rights and stated 61

I would be most reluctant to conclude that the Act, which purports to affirm this commitment, should be construed other than in a manner that gives effect to it.

His honour continued by making reference to a number of decisions of the Human Rights Committee on effective remedies, as well as to similar decisions under the European Convention and the Inter-American Convention. And in a passage similar to one found in Casey J's judgment, Hardie Boys J stated: ${ }^{62}$

Citizens of New Zealand ought not to have to resort to international tribunals to obtain adequate remedy for infringement of Covenant rights this country has affirmed by statute. I consider that the Courts are obligated to provide those remedies by domestic law.

In his judgment, McKay J also relied on the ICCPR. He said: ${ }^{63}$

\footnotetext{
60 Above $n 7$ at $40-41$.

61 Above $\mathrm{n} 7$ at 83.

62 Ibid at 83

63 Ibid at 103-104.
} 
The second part of the Long Title states the further purpose of the Act to affirm New Zealand's commitment to the International Covenant on Civil and Political Rights 1966 . One of the obligations which the International Covenant places on the States Parties is to ensure that an effective remedy is given to persons whose rights are violated: art 2(3). The declared purpose of the New Zealand Bill of Rights Act must be considered in interpreting the Act ... .

In his judgment, Cooke P observed: ${ }^{64}$

The New Zealand Act [ie the Bill of Rights Act] is "(b) To affirm New Zealand's commitment to the International Covenant on Civil and Political Rights." By art 2(3) of the Covenant each State Party has undertaken, inter alia, to ensure an effective remedy for violation ... and to develop the possibilities of judicial remedy.

In light of this and other factors, Cooke $\mathrm{P}$ also held that a monetary compensation jurisdiction existed for breach of the Bill of Rights.

This extended reference to Baigent's case is intended to highlight (a) the direct relevance of international human rights law to legal practice in New Zealand; (b) the importance attached by New Zealand judges to compliance with international human rights obligations where possible; (c) the fact that international human rights law can have an impact even in the absence of a specific corresponding domestic provision; (d) the compliance effect which the existence of international complaint mechanisms can have domestically.

Before concluding this section, a particularly interesting development worthy of note is the weight given to the views adopted by the Human Rights Committee. In $R v$ Goodwin (No 2), the Court of Appeal had to consider the interpretation of section 22 of the Bill of Rights which guarantees "the right not to be arbitrarily arrested or detained". In determining the meaning of "arbitrary" for the purposes of section 22, the Court referred to the jurisprudence of the Human Rights Committee under the ICCPR equivalent provision, article 9(1). Having noted Recital (b) of the Bill of Rights, and without making a final determination, the Court indicated its preference for an interpretation of section 22 which was consistent with the Human Rights Committee's jurisprudence. Significantly, the court observed: ${ }^{65}$

64 Ibid at 57.

65 Goodwin (No 2) above $n 7$ at 321. 
Whether a decision of the Human Rights Committee is absolutely binding in interpreting the New Zealand Bill of Rights Act may be debatable, but at least it must be of considerable persuasive authority.

\section{WHY HAS THE IMPACT OF INTERNATIONAL HUMAN RIGHTS NORMS IN NEW ZEALAND JUDICIAL DECISIONS INCREASED?}

The answer to this question is somewhat speculative, but there appear to be a number of reasons explaining the increased prominence of international human rights norms in New Zealand judicial decisions.

First, as noted earlier, the Long Titles of many human rights statutes explicitly acknowledge their international antecedents and many have been passed to enable New Zealand to ratify the relevant treaty. These references have been legitimately regarded by the courts as parliamentary encouragement to have regard to relevant international norms in interpreting and applying domestic human rights statutes. Indeed, statutory references to the international treaties allow the courts to justify use of international norms and jurisprudence on the basis that it gives better effect to Parliament's intention in enacting the domestic statute.

Second, the universalisation of human rights norms makes it easier for domestic courts to accept that international human rights treaty norms represent civilised values of right conduct which have an inherent merit regardless of their location in an unincorporated treaty.

Third, the courts have become more prepared to assume that international obligations are intended to be taken seriously by New Zealand, and that they have a part to play in actuating them. Thus, rather than fearing that giving effect to international human rights norms would be seen to permit the executive to make law without parliamentary involvement, nowadays the courts are more concerned to ensure that international human rights commitments do not smack of "window-dressing". 66 The courts have realised that unless they utilise international human rights law in their decisions "window-dressing" will be the inevitable result.

Fourth, the availability of international complaint mechanisms has had an impact. The courts have recognised that (unless domestic law explicitly enacts contrary to international law) there is little point in making decisions contrary to international human rights norms

66 The phrase "window-dressing" is used in Tavita above n 7 at 40 and Baigent's case above n 7 at 74 (per Casey J) in connection with Child Convention and ICCPR protections. 
when these are susceptible to challenge on the international plane. Inevitably, this has encouraged counsel to cite, and judges to give effect to, international human rights provisions and jurisprudence. ${ }^{67}$

Fifth, there are more international human rights instruments in existence today which are of relevance to New Zealand than there were a number of years ago. Indeed, it must be recalled that apart from the work of the ILO not much international human rights law existed until after the Second World War. It should not be surprising that it would take time for international developments to make an impact domestically when so many legal practitioners had been trained in ignorance of them. Allied to this point, is the fact that international law though still not compulsory at New Zealand law schools continues to strengthen in terms of its presence on law school curricula.

Sixth, there has been a growth in New Zealand of "rights consciousness". One of the features of this consciousness globally has been utilisation of developments overseas and internationally in order to persuade courts to advance domestic protection of human rights. Moreover, it must be acknowledged that the Court of Appeal during the presidency of Cooke $\mathrm{P}$ was generally more liberal and willing to develop New Zealand law in the human rights field. It was consistent with this philosophy that more reference would be made to international developments as a justification for advancing human rights protection in New Zealand.

\footnotetext{
67 See eg Baigent's case above $\mathrm{n} 7$ at 74 (per Casey J), and Tavita above $\mathrm{n} 7$ at 40-41.
} 
